\title{
PENGEMBANGAN MEDIA PEMBELAJARAN BERBASIS MOODLE PADA MATAKULIAH FISIKA DASAR
}

\author{
Lovy Herayanti*, M. Fuadunnazmi, dan Habibi \\ Program Studi Pendidikan Fisika, FPMIPA IKIP Mataram \\ e-mail: lovy_fis@yahoo.com
}

\begin{abstract}
Abstrak: Tujuan penelitian ini adalah mengembangkan media pembelajaran berbasis moodle untuk perkuliahan Fisika Dasar. Penelitian dilakukan dengan model pengembangan 4D selama dua tahun. Tahun pertama, penelitian terfokus pada pengembangan platform moodle melalui fase define, design, dan develop. Tahun kedua dilakukan penyempurnaan dengan revalidasi produk dan diseminasi. Pengembangan desain platform moodle dilakukan secara offline dan online menggunakan software moodle versi 2.0. Pengembangan secara offline dilakukan untuk mengatur story board, page navigation, profile setting, administration settings, dan management course setting. Pengembangan secara online dilakukan agar pembelajaran fisika dasar dapat diakses di manapun sehingga mahasiswa dapat belajar lebih mudah dan fleksibel. Hasil pengembanga divalidasikan kepada pakar pembelajaran dan diujicobakan kepada mahasiswa. Pengumpulan data respon dilakukan lewat angket dan tes dan hasilnya dianalisis dengn statistik deskriptif. Hasil validasi pakar untuk silabus, SAP, dan kelayakan ketiganya masuk kategori sangat baik/layak sehingga dapat dinyatakan layak untuk digunakan untuk mendukung proses pembelajaran. mahasiswa juga memberikan respon yang positif terhadap media yang dikembangkan.
\end{abstract}

Kata Kunci: media pembelajaran, moodle, fisikadasar

\section{DEVELOPING MOODLE-BASED LEARNING MEDIA FOR BASIC PHYSICS}

\begin{abstract}
This research developsa moodle-based learning media for Basic Physics lecture. It was conducted using 4D development model and took place for 2 years. The first year was focused on developing the moodle platform through defining, designing, and developing phases. The second year was focused on refinement, revalidation, and dissemination. Thedesign of the moodle platform was developed offline and online using moodle software version 2.0. The offline process comprised designing story boards, page navigation, profile settings, administration settings, and management course settings. The platform was then made online so that Basic Physics learning can be accessed anywhere by students easily and flexibly. The results of the development and field tests show that the developed product is feasible to support the learning process. Students respond positively to the moodle-based media.
\end{abstract}

Keywords: Media Learning, Moodle, Basic Physics

\section{PENDAHULUAN}

Perkembangan pesat pada bidang teknologi informasi dan komunikasi dewasa ini, di antaranya dipicu oleh temuan di bidang fisika material melalui penemuan piranti elektronika yang mampu memuat banyak informasi dengan ukuran sangat kecil.

Kemajuan teknologi menawarkan berbagai kemudahan bagi manusia untuk memperoleh informasi dalam waktu singkat. Pemenuhan kebutuhan manusia akan informasi menjadi lebih cepat dengan hadirnya internet. Salah satu manfaat internet bagi pendidikan adalah sebagai media pembelajaran. Terdapat tiga fungsi internet sebagai media dalam kegiatan pembelajaran, yaitu sebagai komplemen (pelengkap), suplemen (tambahan), dan subsitusi (pengganti). Internet sebagai media pembelajaran menjadi salah satu pilihan yang mendukung kegiatan pembelajaran.

Penggunaan teknologi komunikasi dan informasi dalam bidang pendidikan memberikan pengaruh yang sangat besar. Pada proses pembelajaran dirasakan adanya kecenderungan: (1) bergesernya pendidikan dari sistem pembelajaran yang berorientasi pada guru (teacher centered) ke sistem yang berorientasi pada peserta didik (student centered); (2) tumbuh dan makin memasyarakatnya pendidikan terbuka 
dan jarak jauh; (3) semakin banyaknya pilihan sumber belajar yang tersedia (Hermawanto, et al. 2013:68). Rosenberg (2001:8) menambahkan ada tiga pergeseran dalam proses pembelajaran akibat perkembangan teknologi komunikasi yaitu: (a) pergeseran dari ruang kelas ke di mana dan kapan saja; (b) pergeseran dari kertas ke online; dan (c) pergeseran fasilitas fisik ke fasilitas jaringan kerja. Dengan adanya teknologi informasi ini guru dapat memberikan layanan tanpa harus berhadapan langsung dengan peserta didik. Demikian pula peserta didik dapat memperoleh informasi dalam lingkup yang luas dari berbagai sumber melalui ruang maya dengan menggunakan komputer atau internet.

Perkembangan teknologi dan pertumbuhan penggunaan internet di Indonesia beberapa tahun terakhir diduga mempunyai kontribusi positif, terutama dalam kawasan pemanfaatan media internet untuk pembelajaran.

Pemanfaatan teknologi informasi dalam hal ini e-learning memerlukan pendidik yang terampil memanfaatkan teknologi serta teknologi untuk pembuatan bahan ajar. Selain itu juga diperlukan suatu rancangan agar dapat melaksanakan pembelajaran dengan efektif. Dalam sebuah rancangan pembelajaran terdapat suatu proses untuk memandu pelaku untuk mendesain, mengembangkan, menerapkan konten e-learning dengan memanfaatkan infrastruktur dan aplikasi e-learning yang tersedia. Pada tahap selanjutnya dalam implementasi e-learning terdapat tahap evaluasi yang dimanfaatkan untuk merevisi atau penyesuaian terhadap tahap-tahap sebelumnya. Desain instruksional merupakan proses dinamis yang dapat berubah-ubah sesuai dengan informasi dan evaluasi yang diterima bertujuan untuk meningkatkan hasil pembelajaran peserta didik sehingga tujuan pembelajaran dapat tercapai.

E-learning dapat didefinisikan sebagai sebuah bentuk teknologi informasi yang diterapkan di bidang pendidikan dalam bentuk dunia maya. Istilah e-learning lebih tepat ditujukan sebagai usaha untuk membuat sebuah transformasi proses pembelajaran yang ada di sekolah atau perguruan tinggi ke dalam bentuk digital yang dijembatani teknologi internet (Hanum, 2013).

E-learning merupakan salah satu bentuk model pembelajaran yang difasilitasi dan didukung pemanfaatan teknologi informasi dan komunikasi. E-learning mempunyai ciri-ciri, antara lain 1) memiliki konten yang relevan dengan tujuan pembelajaran; 2) menggunakan metode instruksional, misalnya penyajian contoh dan latihan untuk meningkatkan pembelajaran; 3) menggunakan elemen-elemen media seperti kata-kata dan gambar-gambar untuk menyampaikan materi pembelajaran; 4) memungkinkan pembelajaran langsung berpusat pada pengajar (synchronous e-learning) atau di desain untuk pembelajaran mandiri (asynchronous e-learning); 5) membangun pemahaman dan keterampilan yang terkait dengan tujuan pembelajaran baik secara perseorangan atau meningkatkan kinerja pembelajaran kelompok (Clark \& Mayer, 2008:10). Rusman dkk (2011:264) menyatakan e-learning memiliki karakteristik, antara lain (a) interactivity (interaktivitas), (b) independency (kemandirian), (c) accessibility (aksesibilitas), (d) enrichment (pengayaan).

Pembangunan dan pengembangan e-learning saat ini begitu mudahnya dengan perangkat lunak learning management system (LMS) yang disebut moodle. Fitur-fitur penting penunjang pembelajaran tersebut misalnya tugas, quiz, komunikasi, kolaborasi, serta fitur utama yang dapat mengupload berbagai format materi pembelajaran (Surjono, 2011:6). Pendidik dituntut untuk menciptakan suasana belajar yang efektif, inovatif, dan menyenangkan. Dalam proses pembelajaran, pendidik berperan sebagai motivator dan fasilitator. Perubahan paradigma instructional based learning menjadi constructional based learning membuat pendidik harus mendesain pembelajaran yang mengaktifkan peserta didik untuk lebih banyak mengasah skill dengan praktik mandiri.

Usaha untuk mewujudkan proses pembelajaran yang efektif, inovatif, dan menyenangkan yang dapat mengaktifkan peserta didik maka pendidik bisa memanfaatkan semua sumber daya yang ada di sekolah, baik sumber daya manusia, sarana dan prasarana, dan sumber daya yang lain untuk membuat pembelajaran lebih efektif, inovatif, dan menyenangkan. Kata kunci dari e-learning adalah fleksibilitas, kenyamanan, dan kemudahan untuk belajar dimanapun tanpa harus berada di tempat yang sama. Keuntungan lain dari e-learning adalah kemampuan peserta didik untuk beradaptasi dan berkomunikasi dengan temanteman sebayanya tanpa terbatas jarak.

Pemanfaatan e-learning dalam proses pembelajaran diharapkan bisa meningkatkan motivasi dan hasil belajar peserta didik. Selain itu, alur proses pembelajaran tidak harus berasal dari pen- 
didik menuju peserta didik. Peserta didik bisa juga saling belajar dari sesama peserta didik lainnya. Prestasi belajar yang tinggi dapat diraih berkat sinergi dari semua komponen yang membangun pembelajaran itu sendiri. Keberhasilan belajar dipengaruhi oleh banyak faktor, secara garis besar faktor-faktor yang mempengaruhi keberhasilan belajar itu dapat dibagi menjadi dua bagian besar yaitu faktor internal dan faktor eksternal.

Moodle adalah sebuah Open Source Course Management System (CMC), yang berarti tempat belajar dinamis dengan menggunakan model berorientasi objek, juga dikenal sebagai Learning Management System (LMS) atau Virtual Learning Environment (VLE). Moodle merupakan sebuah program aplikasi yang dapat merubah media pembelajaran ke dalam bentuk web. Manfaat dari pengunaan LMS menggunakan Moodle secara online sangat penting, diantaranya adalah mengatasi keterbatasan frekuensi tatap muka antara mahasiswa dengan dosen.

Moodle dalam pembelajaran sains banyak digunakan sebagai salah satu media pembelajaran karena membantu dalam mengajar sains. Hartanto dan Purbo (2005) menyatakan bahwa ada beberapa alasan menggunakan moodle untuk meningkatkan pengajaran, yaitu: (1) mampu memberikan siswa akses ke bahan kursus dalam lingkungan yang terkendali sehingga pembelajaran dapat berlangsung dimana saja; (2) memantau kemajuan dan menyimpan catatan belajar siswa; (3) memperluas kelas dengan menyediakan diskusi online, evaluasi, kegiatan, dan yang paling penting memungkinkan kolaborasi serta komunikasi untuk pembelajaran; (4) memanfaatkan multimedia yang menarik, media 3D interaktif, dan konten berbasis web yang memungkinkan siswa dengan gaya belajar yang berbeda untuk mengakses kurikulum; dan (5) membantu pendidik sains berkolaborasi, berbagi, dan menyimpan sumber daya pengajaran.

Pengembangan media berbasis moodle di IKIP Mataram dapat dilakukan mengingat telah tersedianya fasilitas komputer dan jaringan yang memadai. Semua fasilitas tersebut hanya belum dimanfaatkan secara optimal sebagai pendukung pembelajaran khususnya pembelajaran fisika. Pemanfaatan e-learning dalam pembelajaran khususnya fisika merupakan sebuah terobosan yang diharapkan mampu menambah motivasi peserta didik untuk belajar karena dalam e-learning ada interaksi langsung peserta didik dengan ma- teri, penugasan, dan evaluasi. Interaksi langsung ini merupakan aktivitas belajar yang aktif dari peserta didik, sehingga pendidik dalam pembelajaran berfungsi sebagai fasilitator saja. Hal inilah yang kemudian melatarbelakangi munculnya inovasi-inovasi baru dalam pembelajaran fisika, khususnya penggunaan moodle sebagai media pembelajaran.

\section{METODE}

Penelitian ini merupakan penelitian pengembangan yang menggunakan langkahlangkah dari model pengembangan $4 D$ yaitu; Define, Design, Develop, dan Disseminate. Penelitian pengembangan ini dilakukan selama 2 tahun (2015-2017). Pada tahun pertama difokuskan pada pengembangan platform melalui tiga tahap pengembangan tanpa Disseminate. Desain platform moodle dilakukan secara offline dan online menggunakan software moodle versi 2.0. Cara offline dilakukan untuk mengatur story board, page navigation, profile setting, administration settings, dan management course setting. Cara online dilakukan agar pembelajaran Fisika Dasar dapat diakses secara online di manapun sehingga belajar lebih mudah dan fleksibel. Tahun kedua dilakukan penyempurnaan model Media berbasis moodle yang direvalidasi dan selanjutnya dilanjutkan dengan tahap disseminasi.

Hasil pengembangan kemudian divalidasi oleh pakar media pembelajaran berbasis moodle yang meliputi silabus, SAP, kualitas tampilan media dan kemudahan penggunaan media berbasis moodle. Selin itu, produk juga diujicobakan kepada mahasiswa untuk mendapatkan tanggapan. Data dikumpulkan lewat angket dan tes untuk mahasiswa. Data dianalisis dengan dengan statistik deskriptif.

\section{Hasil \\ Define}

Hasil observasi yang dilakukan, diketahui bahwa masih dideteksi rendahnya rata-rata penguasaan konsep dasar fisika mahasiswa di IKIP Mataram. Hal ini dapat dilihat dari nilai rata-rata fisika mahasiswa sebesar 56,60. Ini menggambarkan banyaknya permasalahan yang dialami mahasiswa dalam belajar fisika yang umumnya terdiri dari konsep yang bersifat abstrak. Visualisasi konsep abstrak dapat dilakukan bantuan media berbasis moodle. Pengembangan media berbasis moodle diharapkan dapat membantu mahasiswa 
dalam belajar fisika, sehingga penguasaan konsepnya menjadi lebih baik.

\section{Design}

Tahap ini dilakukan perancangan $d r a f t$ produk media berbasis moodle yang dihasilkan yang terdiri dari dua bentuk yaitu, story board yang dilakukan untuk simulasi dalam bentuk macromedia flash dan story board untuk media pembelajaran berbasis moodle. Analisis fitur-fitur dalam moodle yang dilakukan yaitu: login dan logout, kursus, download, quiz, chat, forum diskusi dan ujian. Rancangan tersebut ditampilkan pada Tabel 1.

\section{Develop}

Pada tahap develop dilakukan untuk mengembangkan fitur-fitur yang digunakan dalam media pembelajaran. Adapun komponen-komponen yang dihasilkan pada tahap ini dijelaskan melalui Tabel 2.

Berdasarkan hasil yang sudah dilakukan pada tahun pertama yang meliputi tahapan pengembangan di atas, terdapat tiga bagian inti yang harus diatur dalam manajemen moodle, yaitu: (1) tampilan, (2) perkuliahan, dan (3) user/ pengguna. Agar dapat melakukan pengaturan maka terlebih dahulu login dengan memasukkan username dan password, langkah selanjutnya dilakukan dengan memilih "turn editting on". Adapun contoh tampilan moodle yang dihasilkan dapat dilihat pada Gambar 1 dan Gambar 2.

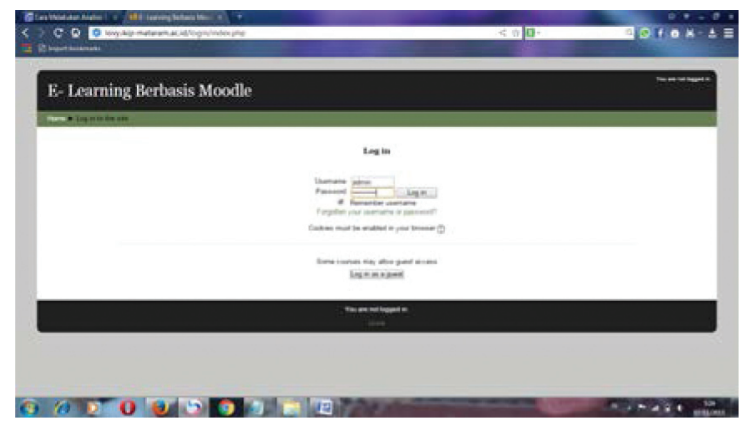

Gambar 1. Page login media moodle

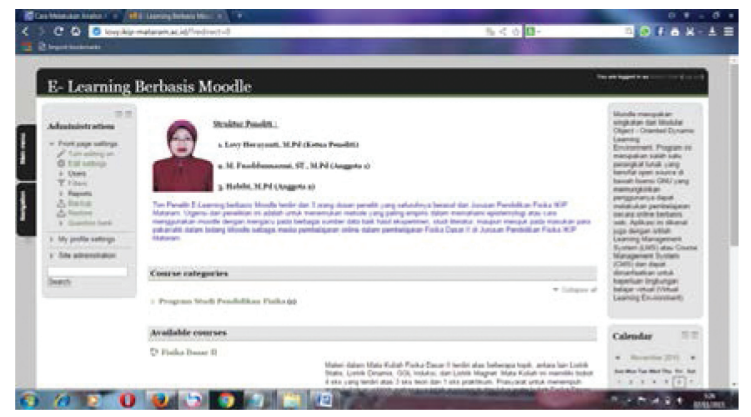

Gambar 2. Tampilan turn on editing

Pada manajemen tampilan, langkah pengaturan yang dilakukan meliputi: full site name, front page description, courses and news item, dan

Tabel 1. Fitur Moodle

\begin{tabular}{ll}
\hline Fitur & \multicolumn{1}{c}{ Keterangan } \\
\hline $\begin{array}{l}\text { Login \& } \\
\text { Logout }\end{array}$ & $\begin{array}{l}\text { Merupakan Link untuk masuk dan keluar media. Kategori untuk masuk dan } \\
\text { keluar madia dibagi menjadi } 3 \text { sesuai dengan user dan password masing- } \\
\text { masing, yaitu: } \\
\text { a. Login/logout sebagai Admin } \\
\text { b. Login/logout sebagai Mahasiswa } \\
\text { c. Login/logout sebagai Dosen }\end{array}$ \\
\hline Course & $\begin{array}{l}\text { Berisi penjabaran materi Fisika Dasar II yang dapat diakses secara mandiri } \\
\text { oleh Mahasiswa sesuai dengan petunjuk yang diberikan. }\end{array}$ \\
\hline Download & $\begin{array}{l}\text { Menampilkan link download untuk mendapatkan animasi serta keperluan } \\
\text { perkuliahan lainnya. }\end{array}$ \\
\hline Quiz & $\begin{array}{l}\text { Berisi soal-soal latihan tiap akhir pertemuan yang telah dirancang sesuai } \\
\text { dengan kebutuhan. }\end{array}$ \\
\hline Chat & $\begin{array}{l}\text { Merupakan sarana dosen dan mahasiswa untuk berinteraksi selama proses } \\
\text { pembelajaran secara tidak aktif. }\end{array}$ \\
\hline $\begin{array}{l}\text { Forum } \\
\text { discuss }\end{array}$ & Memuat sarana diskusi tentang suatu topik materi yang belum dipahami. \\
\hline Exam & $\begin{array}{l}\text { Berisi soal-soal ujian tengah dan akhir semester yang digunakan untuk } \\
\text { mengukur peningkatan indikator kemampuan masing-masing. }\end{array}$ \\
\hline
\end{tabular}


Tabel 2. Hasil Pengembangan Media Moodle

\begin{tabular}{ll}
\hline $\begin{array}{l}\text { Hasil } \\
\text { pengembangan }\end{array}$ & Penjelasan \\
\hline Hosting server & $\begin{array}{l}\text { Hosting server merupakan wadah software. Media pembelajaran berbasis } \\
\text { moodle yang dihasilkan diupload ke hosting server. Hosting server yang } \\
\text { digunakan merupakan milik IKIP Mataram. }\end{array}$ \\
$\begin{array}{l}\text { Domain } \\
\text { Subdomain }\end{array}$ & $\begin{array}{l}\text { Sub domain merupakan bagian dari domain. Alamat sub domain akan } \\
\text { menunjukkan lokasi pembelajaran yang dituju. Sub domain yang digunakan }\end{array}$ \\
adalah lovy.ikip-mataram.ac.id \\
Video Animasi & $\begin{array}{l}\text { Video animasi berisi animasi tentang materi pembelajaran untuk membantu } \\
\text { Mahasiswa memudahkan dalam memahami Materi. }\end{array}$ \\
Buku Panduan & $\begin{array}{l}\text { Buku panduan digunakan sebagai panduan bagi dosen dan mahasiswa. Buku } \\
\text { panduan yang dihasilkan berisi panduan dalam menggunakan media } \\
\text { pembelajaran. }\end{array}$ \\
\hline
\end{tabular}

topic section. Gambar 3 di bawah ini menunjukkan tampilan hasil pengaturan topic section pada moodle.

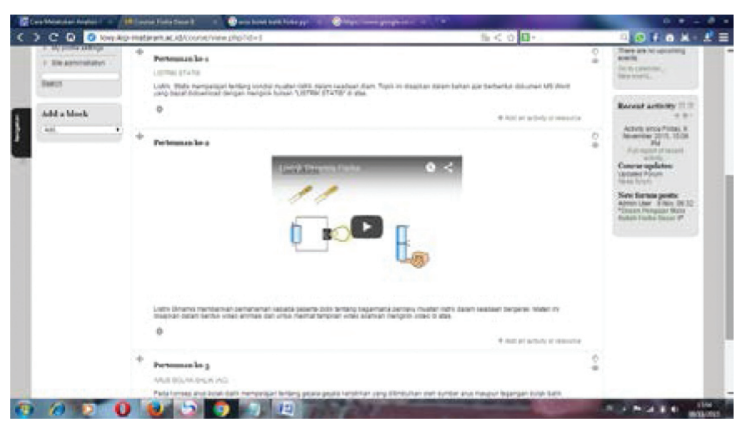

Gambar 3. Pengaturan new page

Pada manajemen user, langkah pengaturan yang dilakukan meliputi: format text, define roles, assign roles, user accounts, lecturing and student. Gambar 4 di bawah ini menunjukkan tampilan pengaturan user accounts.

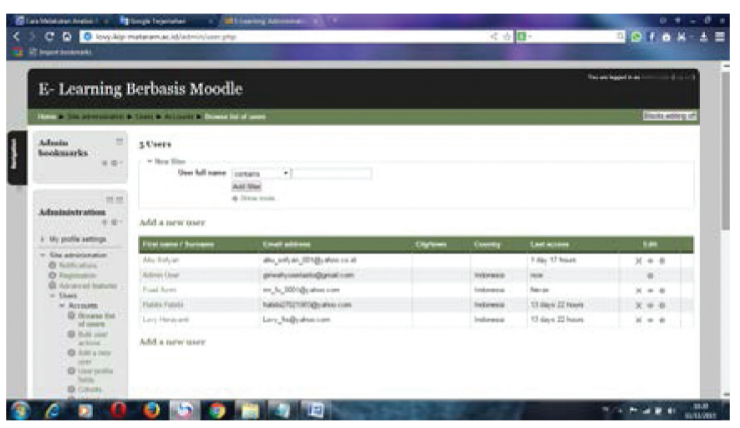

Gambar 4. Tampilan Pengaturan User

Adapun hasil tanggapan mahasiswa terhadap model dapat dilihat pada Tabel 3.
Tabel 3. Hasil Validasi Terhadap Media Berbasis Moodle

\begin{tabular}{|c|c|c|c|}
\hline $\begin{array}{c}\text { Aspek yang } \\
\text { Dinilai }\end{array}$ & Jumlah & Rata-rata & Kriteria \\
\hline $\begin{array}{l}\text { Tampilan } \\
\text { Media }\end{array}$ & 12,8 & 4,3 & SS \\
\hline $\begin{array}{l}\text { Kemudahan } \\
\text { Penggunaan }\end{array}$ & 12,4 & 4,1 & $\mathrm{~S}$ \\
\hline
\end{tabular}

Berdasarkan pengembangan produk Media Moodle, secara rinci skor angket hasil uji coba lapangan dan kriteria kemampuan penguasaan konsep dapat dilihat pada Gambar 5 dan Tabel 4.

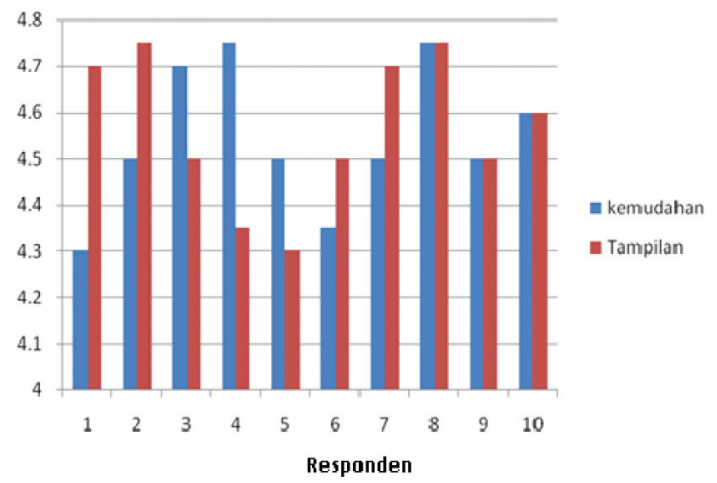

Gambar 5. Grafik Skor Uji Coba Skala Kecil

Tabel 4. Kriteria Kemampuan Penguasaan Konsep

\begin{tabular}{llccc}
\hline $\begin{array}{l}\text { Skor } \\
\text { rata- } \\
\text { rata }\end{array}$ & Bab I & Bab II & $\begin{array}{c}\text { Bab } \\
\text { III }\end{array}$ & $\begin{array}{c}\text { Bab } \\
\text { IV }\end{array}$ \\
\hline Pretes & 18 & 30 & 30 & 30 \\
Postes & 80 & 90 & 95 & 90 \\
N-gain & 76 & 86 & 93 & 86 \\
Kriteria & Tinggi & Tinggi & Tinggi & Tinggi \\
\hline
\end{tabular}


Hasil penelitian menunjukkan skor ratarata untuk penguasaan konsep pada tiap $\mathrm{Bab}$ materi yang diberikan pada media berbasis moodle ditampilkan pada Tabel 3. Persentase skor rata-rata tes awal pada Bab I sampai dengan Bab IV diperoleh sebesar 18\%, 30\%, 30\%, dan 30\%. Persentase skor rata-rata tes akhir berturut-turut diperoleh sebesar $80 \%, 90 \%, 95 \%$, dan $90 \%$.

\section{Pembahasan}

Media pembelajaran berbasis moodle yang dikembangkan oleh peneliti memiliki beberapa karakteristik atau ciri khas. Karakteristik yang terdapat dalam media pembelajaran berbasis moodle sangat erat kaitannya dengan kegiatan pembelajaran. Hal ini sesuai dengan hasil penelitian Andrews dan Daly (2008) yang menjelaskan bahwa media moodle berhasil mendukung penyelanggaraan kolaborasi pengajaran dan pembelajaran di empat Universitas di Australia. Media pembelajaran fisika berbasis moodle yang dikembangkan berbentuk sebuah website pembelajaran yang dapat di akses pada alamat lovy. ikip-mataram.ac.id. Media pembelajaran berbasis moodle ini berisi materi juga dilengkapi dengan contoh soal dan tampilan animasi yang sesuai dengan masing-masing materi. Penggunaan media pembelajaran berbasis moodle dalam penelitian ini dilakukan dengan mengkombinasikan pembelajaran tatap muka dan pembelajaran secara online. Pembelajaran online merupakan suatu sistem yang dapat memfasilitasi peserta didik belajar lebih luas, lebih banyak dan bervariasi (Munir, 2010).

Validasi ahli terhadap media pembelajaran berbasis moodle meliputi kualitas tampilan media dan kemudahan penggunaan media berbasis moodle. Validasi media pembelajaran berbasis moodle dilakukan oleh 2 orang ahli. Berdasarkan hasil validasi dua orang ahli yang direkomendasikan pembelajaran berbasis e-learning moodle ini sudah sangat layak untuk dilakukan uji coba skala terbatas untuk mendapatkan kualitas media yang lebih baik. Hal ini terihat dari skor rata-rata yang diperoleh dari angket penilaian media pembelajaran ini sebesar 4,45 (termasuk dalam kategori baik/layak). Adapun beberapa masukan dari ahli yaitu disarankan membuat tampilan dan materi yang menarik dan lebih baik agar dapat membuat mahasiswa menjadi lebih antusias di dalam belajar mandiri.
Media pembelajaran berbasis e-learning moodle tidak terlepas dari beberapa perangkat pendukung berupa silabus, SAP, LKM, dan buku ajar sebagai pegangan wajib bagi mahasiswa. Silabus dan SAP yang digunakan telah disesuaikan dengan materi dan langkah pembelajaran dengan menggunakan moodle ini. Hasil validasi dari dua orang ahli memberikan skor rata-rata penilaian terhadap silabus dan SAP ini masing-masing sebesar 4,65 (kategori sangat baik) dan 4,4 (kategori sangat baik). Hal ini menunjukkan bahwa silabus dan SAP yang digunakan telah sesuai dengan penggunaannya di dalam pembelajaran.

Buku ajar Fisika Dasar II yang dibuat telah disesuaikan dengan materi yang diberikan di dalam e-learning sehingga mahasiswa dapat lebih mudah mempelajari materi yang diberikan baik secara online maupun dari buku pegangannya. Buku ajar ini dibuat sebagai pendukung dari media pembelajaran moodle yang telah dikembangkan. Hasil validasi ahli juga memberikan penilaian kategori sangat layak dengan skor ratarata tiap item pernyataan yang diberikan yaitu sebesar 4,8 (kategori sangat baik/layak). Adapun selain skor tersebut juga diberikan beberapa masukan seperti tata letak dan efisiensi penulisan terutama pada kalimat yang sama ditiap bab yang dijadikan sebagai bahan revisi untuk selanjutnya di ujicobakan.

Angket digunakan untuk menjaring tanggapan mahasiswa terhadap media pembelajaran berbasis moodle dengan menggunakan skala Likert. Indikator dalam angket yang digunakan diadaptasi dari Widyoko (2012).

Media pembelajaran fisika berbasis moodle yang dikembangkan berbentuk sebuah website pembelajaran yang dapat diakses oleh mahasiswa. Munir 2010 mengemukakan bahwa LMS adalah pengelolaan interaksi dalam suatu proses pembelajaran berbasis teknologi melalui website. Perangkat lunak pendukung model LMS yang digunakan adalah moodle. Media pembelajaran yang dikembangkan ini berisi materi juga dilengkapi dengan contoh soal dan tampilan animasi yang sesuai pada masing-masing materi. Berdasarkan hasil studi pendahuluan berupa survey dan wawancara yang dilakukan dengan beberapa dosen pengampu mata kuliah Fisika Dasar menyatakan bahwa media pembelajaran berbasis moodle perlu dikembangkan karena belum tersedia khususnya di IKIP Mataram. Kemampuan mahasiswa terhadap kecakapan teknologi 
informasi saat ini sebagian besar sudah tidak perlu diragukan lagi, sehingga dapat mendukung dalam penerapan media pembelajaran berbasis moodle di dalam perkuliahan.

Fitur yang terdapat dalam moodle sesuai dengan kelas online dan lebih baik digunakan untuk tambahan dari pembelajaran melalui tatap muka di kelas. Moodle menyediakan banyak pilihan fitur. Semua fitur yang tersedia dibuat untuk mendukung kegiatan pembelajaran sebagaimana mestinya. Dalam penelitian ini fitur yang digunakan antara lain activities, resources, forum, quizzes dan assignments.

Penggunaan media pembelajaran berbasis moodle yang dikembangkan dilakukan dengan mengkombinasikan pembelajaran tatap muka dan pembelajaran online. Pembelajaran online merupakan suatu sistem yang dapat memfasilitasi peserta didik belajar lebih luas, lebih banyak dan bervariasi. Pembelajaran online lebih berfungsi sebagai pendukung kegiatan tatap muka. Arifin, Y \& Sidin, U.S. (2009) menjelaskan bahwa $E$ learning membawa pengaruh terjadinya proses transformasi sistem pendidikan konvensional kedalam bentuk digital, baik secara isi dan sistemnya. Dalam penelitian ini dikembangkan media pembelajaran berbasis moodle yang merupakan suatu website pembelajaran. Terdapat materi, bahan ajar serta evaluasi yang disajikan dalam bentuk digital sehingga terjadi perubahan sistem pembelajaran. Tujuan teknologi pembelajaran menurut Surjono \& Gafur (2010:163) adalah membantu, memicu, dan memacu proses belajar peserta didik serta memberikan kemudahan atau fasilitas belajar. Penggunaan e-learning memberikan nuansa baru dalam dunia pendidikan yang selama ini menjadikan pendidik sebagai pusat proses pembelajaran.

Uji coba skala kecil dilakukan dengan mengimplementasikan produk yang telah divalidasi oleh ahli yang dilakukan secara offline. Uji coba ini bertujuan untuk menilai beberapa aspek, yaitu tampilan media secara keseluruhan, keterbacaan tulisan, keterbacaan gambar, kemudahan dalam menggunakan media berbasis moodle dan kemudahan penyampaian konsep dalam media pembelajaran berbasis moodle. Hasil penilaian produk media pembelajaran berbasis moodle dari beberapa aspek yang dinilai memberikan hasil yang memuaskan. Rata-rata skor keseluruhan dari responden memberikan respon yang sangat baik dan memiliki daya tarik bagi responden. Selain itu latihan-latihan soal dan umpan balik, akses pada materi pembelajaran, petunjuk pengoperasian penggunaan moodle sebagai media pembelajaran dapat dipahami dengan baik oleh responden. Oleh karena itu secara deskriptif media moodle dapat dikatakan memiliki fungsi yang tepat untuk menarik minat belajar mahasiswa, khususnya dalam bidang ilmu pendidikan Fisika.

Berdasarkan skor persentase rata-rata yang diperoleh setiap Bab materi yang diberikan ditunjukkan bahwa skor rata-rata tes akhir Mahasiswa berkisar di atas $80 \%$. Selisih skor tes awal dan tes akhir yang tinggi mengiformasikan bahwa Mahasiswa yang mengikuti mata kuliah dengan media moodle dapat meningkatkan kemampuan penguasaan konsep Mahasiswa menjadi lebih baik.

Perbandingan skor $N$-Gain yang diperoleh setiap Bab materi berturut-turut diantaranya yaitu; Bab I memperoleh skor $N$-gain sebesar 76, Bab II sebesar 86, Bab III dan Bab IV berturut-turut sebesar 93 dan 86. Semua skor secara keseluruhan dikategorikan dalam kategori tinggi.

Tabel 5. Perbandingan nilai $\mathrm{N}$-gain Penguasaan Konsep Tiap Bab

\begin{tabular}{lll}
\hline Keterangan & Materi & N-gain \\
\hline Bab I & Listrik Statis & 76 \\
Bab II & Listrik Dinamis & 86 \\
Bab III & Kemagnetan & 93 \\
Bab IV & Rangkaian RLC & 86 \\
\hline
\end{tabular}

Skor N-gain pada materi Bab III lebih mendominasi dari skor gain yang lainnya, namun semua skor dapat disimpulkan telah memenuhi kategori kemampuan tinggi. Penguasaan konsep peserta didik menunjukkan kemampuan peserta didik dalam memahami suatu konsep baik teori ataupun penerapannya dalam kehidupan sehari-hari. Indikator penguasaan konsep dalam penelitian dihubungkan dengan tingkat berpikir domain kognitif Bloom. Kuswana (2014:17) mengkategorikan tujuan mulai dari faktual hingga konseptual terdiri dari enam tingkatan aspek yang berbeda-beda, yaitu aspek pengetahuan, aspek aplikasi, aspek analisis, aspek sintesis, dan aspek evaluasi.

Pada matakulian fisika dasar II terdapat banyak konsep-konsep abstrak yang harus dipahami oleh peserta didik. Oleh karena itu diperlu- 
kan media pembelajaran sebagai alat agar peserta didik dapat memahami konsep-konsep yang bersifat abstrak. Salah satu media pembelajaran yang digunakan adalah media pembelajaran berbasis moodle. Media pembelajaran berbasis moodle ini terdiri atas vidio, gambar, dan animasi sehingga peserta didik dapat mengetahui secara langsung dan memahami konsep yang berkaitan dengan materi tersebut. Penelitian ini menunjukkan adanya pengaruh e-learning berbasis moodle terhadap penguasaan konsep peserta didik. Peningkatan penguasaan konsep melalui pembelajaran fisika menggunakan e-learning berbasis moodle merupakan implikasi dari pembelajaran menggunakan bantuan e-learning yang disajikan melalui website dengan beberapa keunggulan. Pada Tabel 4, diperlihatkan bahwa E-learning dapat meningkatkan pemahaman siswa dan penguasaan konsep serta memperbaiki sikap belajar mahasiswa.

Komputer dalam pengajaran juga dapat meningkatkan pemahaman konsep mahasiswa serta kemampuan individu mendapatkan informasi di masyarakat. Melalui e-learning materi pembelajaran dapat diakses kapan saja dan dari mana saja, disamping itu materi yang dapat diperkaya dengan berbagai sumber belajar termasuk multimedia dengan cepat. Pemanfaatan e-learning moodle dalam pembelajaran dapat diterapkan untuk mata pelajaran selain Fisika. Peningkatan penguasaan konsep melalui pembelajaran fisika menggunakan e-learning berbasis moodle merupakan implikasi dari pembelajaran menggunakan bantuan e-learning yang disajikan melalui website dengan beberapa keunggulan sesuai dengan fiturfitur yang disediakan.

Pembelajaran berbasis moodle membuat penguasaan konsep peserta didik lebih baik. Hasil yang di peroleh sesuai dengan pendapat Husni, A., Juanda, E.A. \& Hamidah, I. (2010) bahwa media E-Learning berbasis moodle efektif menigkatkan penguasaan konsep peserta didik. Hasil wawancara dengan peserta didik yang memiliki nilai terendah dan tertinggi mengatakan bahwa peserta didik mendapat informasi yang lebih dari internet dan menyatakan pembelajaran ini lebih praktis dan efisien karena peserta didik dapat bertanya kepada pendidik secara online ketika peserta didik di dalam kelas kurang bisa memahami.

Fasilitas yang disiapkan dalam pembelajaran berbasis moodle antara lain materi dalam bentuk teks, gambar, simulasi, animasi yang interaktif, penugasan, chat, dan kuis. Peserta didik dapat menggunakan fasilitas yang ada pada pembelajaran online berupa penugasan, chat, dan kuis maka pengetahuan atau wawasan yang mereka dapat lebih banyak.

Berdasarkan hasil penelitian dan temuan terhadap implementasi dalam matakuliah fisika dasar II menggunakan e-learning berbasis moodle, maka dapat dikemukakan keunggulan dan kelemahannya. Adapun keunggulan menggunakan e-learning berbasis moodle yaitu: 1) pembelajaran berpusat pada peserta didik; 2) modul e-learning dapat di simpan dalam leptop yang dapat dibawa kemana-mana dan dapat dibuka baik di kampus maupun di rumah; 3) peserta didik dapat megikuti kuis kapan dan dimana saja asal terhubung melalui internet.

Selain memiliki kelebihan, e-learning juga memiliki kelemahan. Rosenberg (2001) mengemukakan bahwa kelemahan yang dimaksud antara lain sebagai berikut. Pertama, kurangnya interaksi antara pendidik dan peserta didik atau bahkan antar peserta didik itu sendiri. Kedua, kecenderungan mengabaikan aspek akademik atau aspek sosial dan sebaliknya mendorong tumbuhnya aspek bisnis/komersial. Ketiga, proses belajar dan mengajarnya cenderung ke arah pelatihan daripada pendidikan. Keempat, berubahnya peran pendidik dari yang semula menguasai teknik pembelajaran konvensional, kini juga dituntut mengetahui teknik pembelajaran yang menggunakan ICT. Kelima, peserta didik yang tidak mempunyai motivasi belajar yang tinggi cenderung gagal. Keenam, tidak semua tempat tersedia fasilitas internet. Ketujuh, kurangnya tenaga yang mengetahui dan memiliki ketrampilan internet. Kedelapan, kurangnya penguasaan bahasa komputer.

Selanjutnya, wawancara dilakukan terhadap peserta didik serta melakukan kajian terhadap hasil tes penguasaan konsep peserta dididk. Berdasarkan hasil wawancara dan analisis peneliti, dirumuskan beberapa faktor yang menyebabkan tercapainya target yang ditentukan, yaitu sebagai berikut. (1) Alokasi waktu pembelajaran yang sesuai sehingga menyebabkan pembelajaran berjalan secara optimal. (2) Lebih dari $80 \%$ peserta didik membaca materi yang telah disediakan melalui media moodle. Hal ini ditunjukkan dengan banyaknya peserta didik yang melakukan kegiatan melalui media moodle. (3) Lebih dari $95 \%$ peserta didik yang mengikuti evaluasi yang disediakan melalui media moodle. Hal ini di- 
sebabkan karena evaluasi yang diberikan melalui media moodle di tiap pertemuan dapat dijadikan latihan soal bagi peserta didik. (4) Pemberian tugas mendapatkan tindak lanjut oleh pendidik sehingga dapat membantu peserta dididk dalam meningkatkan penguasaan konsep.

\section{SIMPULAN}

Hasil pengembangan media moodle dinyatakan 'layak' untuk digunakan demi mendukung proses pembelajaran dalam perkuliahan. Mahasiswa memberikan respon yang positif serta dapat meningkatkan motivasi belajar mereka. Produk yang dikembangkan juga memiliki keunggulan dalam meningkatkan kualitas pembelajaran yang lebih menarik dan terkontrol. Dosen dan Mahasiswa secara otomatis memperoleh pengalaman mengajar dan belajar yang lebih baik dalam penggunaan teknologi informasi.

Selain itu, juga disarankan agar pembelajaran e-learning berbasis moodle di IKIP Mataram dapat dijadikan sebagai alat bantu pada pembelajaran. E-learning dapat dimanfaatkan untuk meningkatkan pemahaman materi dan memperluas sumber materi ajar maupun menambah aktivitas belajar serta membantu dosen dalam mengefisienkan waktu pembelajaran di dalam kelas. IKIP Mataram telah memiliki e-learning yang aktif dan memiliki sarana dan prasarana pembelajaran online, sehingga e-learning dapat dimanfaatkan untuk proses pembelajaran dan meningkatkan aktivitas belajar mahasiswa.

\section{UCAPAN TERIMA KASIH}

Tim peneliti mengucapkan terimakasih yang sebesar-besarnya kepada Direktorat Riset dan Pengabdian Kepada Masyarakat, Direktorat Jenderal Penguatan Riset dan Pengembangan, Kementerian Riset, Teknologi, dan Pendidikan Tinggi (RISTEKDIKTI) yang telah membiayai penelitian ini melalui skim Hibah Bersaing Tahun 2015-2017.

\section{DAFTAR PUSTAKA}

Andrews, T., Daly, C. 2008. "Using Moodle, An Open Source Learning Management System, to Support a National Learning and Teaching Collaboration". Paper Presented at Proccedings of the 2008 AaeE Conference, Yeppoon copyright : Australia. pp. (1-6).
Arifin, Y \& Sidin, U.S. 2009. "Faktor-Faktor Terpenting dalam Pembangunan E-Learning System". Jurnal MEDTEK, 1 (1): 1.

Clark, R.C.\& Mayer, R.E. (2008). E-Learning and the Science of Instruction: Proven Quidelines For Consumers and Designers of Multimedia Learning, Second Edition. San Francisco: John Wiley \& Sons, Inc.

Thursan, Hakim. 2005. Belajar Secara Efektif. Puspa Swara: Jakarta.

Hanum, Numiek Sulistyo. 2013. "Keefektifan E-Learning Sebagai Media Pembelajaran (Studi Evaluasi Model Pembelajaran E-Learning SMK Telkom Sandhy Putra Purwokerto)". Jurnal Pendidikan, Vol. 3, No. 1.

Hartanto, A.A dan Purbo, O.W. 2005. Teknologi ELearning Berbasis php dan mysql. Jakarta: Elek Media Komputindo.

Hermawanto, et al. 2013. "Pengaruh Blended Learning terhadap Penguasaan Konsep dan Penalaran Fisika Peserta Didik Kelas X”. Jurnal Pendidikan Fisika Indonesia. ISSN: 1693-1246.

Husni, A., Juanda, E.A. \& Hamidah, I. 2010. "Model Pembelajaran Kooperatif Berbantuan Web Pada Materi Fluida Statis Untuk Meningkatkan Pemahaman Konsep Siswa SMA". Prosiding Seminar Nasional Fisika 2010. p 451-458.

Kuswana, Wowo S. 2014. Taksonomi Kognitif, Perkembangan Ragam Berpikir. PT Remaja Rosdakarya. Bandung.

Munir. 2010. "Penggunaan Learning Management System (LMS) di Perguruan Tinggi: Studi Kasus di Universitas Pendidikan Indonesia", dalam Cakrawala Pendidikan, XXIX (2), hlm.109- 119.

Rosenberg, M.J. 2001. E-Learning: Strategies for Delivering Knowledge in the Digital Age. McGraw-Hill Professional. 
Rusman, dkk. 2011. Pembelajaran berbasis teknologi informasi dan komunikasi, mengembangkan profesionalitas guru. Jakarta: PT. Raja Grafindo.

Surjono, Herman Dwi. 2011. Membangun Course E-Learning Berbasis Moodle. UNY Press: Yoyakarta.
Surjono, Herman Dwi \& Gafur, Abdul. 2010. "Potensi Pemanfaatan ICT untuk Peningkatan Mutu Pembelajaran SMA di Kota Yogyakarta" dalam Cakrawala Pendidikan, XXIX (1), hlm.161-175.

Widyoko, S.E.P. 2012.Teknik Penyusunan Instrumen Penelitian. Yogyakarta: Pustaka Pelajar. 